SCHOLEDGE International Journal of

Management \& Development

ISSN 2394-3378, Vol.06, Issue 2

$\operatorname{Pg} 7-24$.

DOI: 10.19085/journal.sijmd060201
Published by: SCHOLEDGE Publishing

www.theSCHOLEDGE.org

Email: editorial@thescholedge.org

\title{
Nine Indicators to Assess the Financial Issues of Local Government Administrations in Haiti
}

\author{
Christophe Providence \\ Teacher-Researcher, Quisquéya University, Haiti \\ Member of the Research Center in Management and Economics of Development (CReGED) \\ Guest at the Laboratory of Management, Economics, Mathematics, Computer Science and \\ Decision Support (memiad) of the University of the Caribbean-Martinique
}

\begin{abstract}
The measurement of the financial issues of local public administrations has never been addressed in the scientific literature on Haiti, either from the point of view of accountability or the evaluation of local public actions. However, the provision of local public goods and services depends on the financial situation of these local public administrations. In this paper, the financial measurement model will be based on nine indicators, three for financial sustainability, three for financial flexibility and three for financial vulnerability. The results demonstrated not only the difficulties faced by municipalities in the West Department in financing their supply of local goods and services to taxpayers, but also the profound disparities in the evolution of their financial health over the period 2015-2018.
\end{abstract}

Key words: Local finance, local development, public administration, accountability, financial situation, community participation, local budgets, local authority, public service provision, provision of public good, proximity.

\section{Introduction}

The purpose of this article is to assess the financial Issues of Haitian communal administrations has never been raised in the scientific literature. Although the funding of local and regional authorities has always been the subject of much debate among devotees of decentralization (Oriol et al., 1994, Dorner, 2006, Providence, 2010). As a result, a tool to measure their financial issues becomes necessary to understand their situation and suggest ways to transform it. 
Measuring the financial issues of governments has been the subject of many concerns in developed countries such as Canada. Whether from an accountability or public policy evaluation point of view, the rationale relies on measurable indicators to facilitate understanding of the relevance of public decisions (Bern and Schramm, 1986; Clarck, and Ferguson, 1988, ICCA, 1997). The objective of measuring the financial issues of governments is to determine whether expenditures were made in a balanced budget and effectively. It is therefore the cost-effectiveness ratio of public actions that is sought through the financial indicators.

Meanwhile, the fall of the Duvalier on February 7, 1986, and the adoption of the new constitution on March 29, 1987, the notion of public actors has been expanding, making local authorities the very foundation of localized public actions. In addition to the central administration, there are the local administrations (Department, Commune and Communal Section) which are called upon to provide local goods and public services to taxpayers (Providence, 2015, Guillaume and Providence, 2019). This transfer of skills also implies a transfer of resources that should enable the local authorities to fulfill their mission of public services. But more than three decades later, the findings show that only the municipal administration remains functional and under difficult financial conditions (Oriol et al., 1994, Providence, 2010).

In this paper, we want to question the principle of administrative and financial autonomy of local governments by reviewing their financial issues. The latter can explain the choice of supply of local public goods and services and thus look at the effectiveness of the territorial financing system. In fact, it is a question of proposing an instrument capable of measuring the evolution of local public finances responsible for the provision of local public goods and services to citizens. Taking the case of the municipalities of the Department of the West over a period of three years (2015-2018), our concern becomes:

\section{Questions and Hypotheses}

Are there any differences in the financial issues of municipalities in the metropolitan area changing compared to other municipalities?

The investigator supports one of the following assumptions:

Ho: No, there are any differences in the financial issues of municipalities does not truly distinguish those in the metropolitan area from others because of their inability to generate high self-financing.

H1: Yes, there are any issues in the financial issues of the municipalities makes it possible to really distinguish those of the metropolitan region from the others by their ability to generate a high self-financing. 


\section{Purpose of this Study}

The purpose of this paper is to propose a model for measuring the financial situation of Haitian local governments, inspired by that developed by Beauregard (2003). It takes the three basic notions of financial issues (viability, flexibility and vulnerability), but using other indicators more adapted to the Haitian context. This choice is justified by the fact that the financial situation is not optimal for local authorities, which considerably limits their ability to mobilize significant own resources. This is an important finding that involves considering areas of uncertainty created by the central government to interfere in the affairs of Haitian local governments.

In a first point, this paper discusses the need to measure the financial position of public administrations. In a second point, he discusses the skills and means transferred to communal communities in Haiti. Then thirdly, it presents a model of measurement of the financial issues of the municipal administrations before applying this test, in a fourth point, to the municipalities of the department of the West. Finally, it concludes on the financial situation of the local administrations and the tracks of deepening of the model.

For Bern and Schramm (1986), good financial health implies that public administrations can respect the balance between their revenues (sources of funding) and their expenditures (supplies of public goods and services). They proposed a model of analysis based on the influence of internal factors (income, expenses, debts and pension fund, etc.) and external factors (economic, political or demographic) on the financial health of a government administration. This assessment of the financial health of governments will be simplified by Clarck and Ferguson (1988) who simply seek to measure the balance between revenues and expenditures of these governments. When expenses exceed income, the balance is broken by creating a tension indicative of a worrying financial health.

The Canadian Institute of Chartered Accountants (CICA, 1997) has proposed a tool for measuring the financial health or accountability of senior governments (the federal and provincial governments). Its model is based on 10 indicators emanating from three aspects of public finances: sustainability, flexibility and vulnerability. Sustainability refers to the government's ability to maintain its services and meet its current obligations. For the CICA (1997), sustainability indicators are government net public debt as a percentage of gross domestic product (GDP) and the government deficit as a percentage of GDP Flexibility, on the other hand, assumes that the government has a margin to increase its financial resources. For this flexibility, the ICCA (1997) highlights three other indicators: public debt charges in terms of the proportion of total revenue, the coefficient of variation of tangible assets and own revenues as a proportion of GDP. Finally, vulnerability reflects the degree of dependence on external sources of funds. Five indicators are used by the CICA (1997) to identify vulnerability: the current account balance of the entire Canadian public sector in terms of the proportion of the GDP (1); analyzing the total external debt of the Canadian public sector in terms of the proportion of GDP (2); transfers from the 
federal government to the provinces according to their own provincial government revenues (3); the external debt in relation to the total debt of the government studied (4); its foreign currency debt in relation to its net debt (5).

Beauregard (2003) makes a marriage between the model of Bown (1993) and that of the ICCA (1997) while simplifying them. It relies on eight indicators to assess the financial health of a local government. The three aspects of the sound financial health of a municipal administration are very revealing of its strategic direction. Financial viability implies that the administration (national or local) can guarantee the supply of goods and services while fulfilling its obligations to its creditors. The financial flexibility of a municipal administration reflects its ability to increase its financial resources to meet its missions. Finally, financial vulnerability considers the situation of financial dependence of a local administration vis-à-vis other financial actors.

The first three (the size of the debt, the budget balance and the importance of capital expenditures) measure sustainability, the following four (the burden of debt service, the size of the accumulated surplus, fiscal effort and the importance of inelastic expenses) show flexibility and the last indicator (the proportion of income from property taxes) attest to vulnerability. For most of its indicators, Beauregard (2003) uses land wealth as the denominator in place of the population in the Bown model (1993). It is important to note the progressive nature of changes in the financial situation (finances deteriorate or improve gradually) of a local government that even justifies the importance of accountability. In other words, the instrument proposed by Beauregard (2003) seeks to draw attention to the need to monitor the evolution of local public finances responsible for the provision of local public goods and services to citizens.

I- Important skills and limited financial means granted to local authorities in Haiti The principle of decentralization implies a sharing of responsibility between the central public administration and the local public administrations to better manage the territory and to provide local public goods and services to the population. This unitary (but decentralized) system therefore obliges the State to set up a parallel deconcentrating of public services to support the process of decentralization (Providence, 2010; 2018). The difference between these two processes (decentralization and deconcentrating) lies in the fact that decentralization presupposes autonomy (administrative and financial) while deconcentrating reflects the extension of the services of the central administration, always according to clear hierarchical links.

Inspired by the work on the financial health of government administration, Bown (1993) and Beauregard (2003) decide to focus on cities and metropolitan agglomerations. Their approach was to arrive at a simple and quick-to-use measurement tool by managers to assess the financial health of municipal governments. For Bown (1993), this exercise should be based on the following ten indicators: total income per capita (1), local-source 
income (2), transfer income from the general fund (3), the proportion between operating expenditures and total expenditures (4), the balanced budget (5), the size of the accumulated surplus or deficit relative to general revenues (6), liquidity and investment compared to liabilities short-term (7), short-term liabilities versus general revenues (8), debt per capita (9), and debt service to income (10). According to him, one can compare the evolution of the financial situation of a municipality over a period and with respect to other municipalities, by means of these indicators.

For its part, Beauregard (2003) makes a marriage between the model of Bown (1993) and that of the ICCA (1997) while simplifying them. It relies on eight indicators to assess the financial health of a local government. The three aspects of the sound financial health of a municipal administration are very revealing of its strategic direction. Financial viability implies that the administration (national or local) can guarantee the supply of goods and services while fulfilling its obligations to its creditors. The financial flexibility of a municipal administration reflects its ability to increase its financial resources to meet its missions. Finally, financial vulnerability considers the situation of financial dependence of a local administration vis-à-vis other financial actors.

Local and regional authorities represent the pillar of the post-dictatorial Haitian state according to the wishes of the 1987 constitution. This one gives them five general vocations: (a) to participate in the establishment of a political system; (b) to ensure the political representation of the whole population in national or local decisions; (c) to stimulate local initiatives for economic, social and cultural development; (d) to provide partial or complete coverage of public and collective services; (e) to ensure consultation and participation of the whole population in major national decisions. The legal provisions devote 11 fields of technical expertise to them:

1) Regional development and planning

2) Land domain management

3) The environment and natural resources

4) Health and public hygiene

5) Education, literacy and training

6) Culture, sports and recreation

7) Civil protection, assistance and relief

8) Funeral homes and cemeteries

9) Water and electricity

10) Markets and slaughterhouses

11) Public safety

The communal authority's own revenues include the contribution fancier of proprieties bâties (CFPB), the patent and other tax revenues (Certificate of sale of livestock, Right of alignment/building permit, slaughter duty, Certificates/Certificates, etc.). To compensate 
for the weakness of the local authority's own resources, the government provides it with an allocation from the "Fonds de Gestion et de Development des CollectivitiesTerritorials" (FGDCT). The larger this endowment, the more hypothetical is the autonomy of the communal community. This results in the inability of the local authority to diversify its sources of financing, to set up local public industrial or commercial companies. As for the extraordinary resources of a municipality, they are most often the funding either from donors within a specific framework or from the central government, most often to provide a political response to a local need.

Taking into account the specificities of Haitian municipalities, we propose nine indicators in our financial evaluation model. Three indicators to measure "financial sustainability," three others to measure "financial flexibility" and three indicators to assess "financial vulnerability." Some indicators in our model correspond to aspects mentioned in Beauregard's (2003) model and others are specific to the Haitian context.

II- A model for measuring the financial situation of municipal administrations in Haiti Like Brown (1993) and Beaurepart (2003), we believe that a comparative test can help diagnose the financial health of a municipality. This analysis tool must be simple, but effective in order to allow, among other things, other actors involved in localized public actions (local associations, NGOs, etc.) to be aware of local needs and to cooperate with the municipal administration. In Haiti, there are several reasons for using such a measurement tool, as the methodological approach can be conclusive. For example, how to determine the budgetary room for maneuver of local authorities to deal with unforeseen circumstances? It should be stressed that these unforeseen events are of a varied nature, such as natural disasters or the location choices of companies or the migration choices of taxpayers based on perceived opportunities in a municipal territory.

(a) Indicators for assessing the financial health of municipalities

Financial viability expresses a municipality's own financing potential and its ability to mobilize its own resources. Three indicators of financial sustainability are used. First, the self-financing of services, which is a key indicator for assessing financial viability, as it provides information on what own revenue represents in operating expenditure. In this model, a high ratio is favorable. Secondly, the self-financing of goods is also an important indicator that reflects the municipality's ability to mobilize other resources for the provision of local public goods. This is another ratio reducing own revenue over capital expenditure and other operating expenditure (i.e. operating expenditure which is compressible). For us a high score would be favorable. Finally, the third indicator is the importance of capital expenditures. As in Beauregard's (2003) model, and indicator, measures the share of expenditures devoted to infrastructure maintenance and renewal. Here, we use capital expenditures as a proportion of the municipality's total expenditures. A high ratio will reflect a favorable event. 
Financial flexibility, on the other hand, reflects the flexibility available to the municipality to improve its financial performance and to deal with any shocks that may arise. It can be measured by three indicators: the tax effort, the importance of incompressible expenditures and the importance of trade initiatives. The tax effort corresponds to what Beauregard (2003, p. 69) calls: "the amounts required from taxpayers by the municipality." In our model, it is reflected in what property taxes (CFPB) represent in a municipality's own resources. A low value of the ratio corresponding to this indicator is favorable. The importance of incompressible expenses is another indicator to measure the financial flexibility of a local authority. This indicator indicates the latitude of a municipality to deal with problematic situations that may arise (Beauregard, 2003). To calculate this ratio, we refer to all incompressible expenses in the Haitian municipality (remuneration expenses, service and miscellaneous expenses and miscellaneous consumer expenses) as a proportion of its total expenses. A low value of this one corresponds to a favorable situation. The third indicator, the importance of commercial initiatives, is calculated by reducing the revenues of the patent to the product of the population and the size of the municipality. This gives an idea of the municipality's latitude to facilitate the development of economic activities on its territory. A high value of this ratio reflects a favorable situation.

Financial vulnerability determines the municipality's financial dependence on its partners, which significantly reduces its ability to defend its administrative and financial autonomy. This notion invites us to consider three last indicators: the proportion of tax revenues, the proportion of the government's endowment and the ratio of funding sources. The proportion of tax revenues reflects the municipality's ability to raise its own revenues in relation to its total revenues. This would attest to the municipality's financial autonomy. When this proportion is high, the municipality will have more financial autonomy from the central government. A low value of the ratio corresponding to this indicator is favorable. The second indicator, the proportion of central government funding, focuses on the weight of the Local Government Management and Development Funds (LMDFs) in the municipality's ordinary revenue. A high value of this ratio is favorable. Finally, external financial support is an important indicator for understanding a municipality's financial vulnerability. It is calculated by reconciling the extraordinary revenues, added to the CTDF, with the total revenues. The high value of the ratio corresponding to this indicator is favorable. 
Tableau 1 : Présentation des indicateurs de notre modèle d'analyse de la santé financière de la collectivité communale haïtienne

\begin{tabular}{|c|c|c|}
\hline Variables & Calcul du ratio & Interprétation \\
\hline \multicolumn{3}{|l|}{ La viabilité financière } \\
\hline $\begin{array}{l}\text { L'autofinancement des } \\
\text { services }\end{array}$ & $\begin{array}{l}\text { Recettes propres par rapport aux } \\
\text { dépenses de fonctionnement }\end{array}$ & $\begin{array}{l}\text { Un ratio élevé est } \\
\text { favorable }\end{array}$ \\
\hline L'autofinancement des biens & $\begin{array}{l}\text { Recettes propres par rapport aux } \\
\text { dépenses d'investissement et autres } \\
\text { dépenses de fonctionnement }\end{array}$ & $\begin{array}{l}\text { Un ratio élevé est } \\
\text { favorable }\end{array}$ \\
\hline $\begin{array}{l}\text { L'importance des dépenses } \\
\text { d'immobilisation }\end{array}$ & $\begin{array}{lll}\text { Dépenses d'investissement } & \text { par } \\
\text { rapport aux dépenses totales de la } \\
\text { municipalité }\end{array}$ & $\begin{array}{l}\text { Un ratio élevé est } \\
\text { favorable }\end{array}$ \\
\hline \multicolumn{3}{|l|}{ La souplesse financière } \\
\hline L'effort fiscal & $\begin{array}{l}\text { Impôt foncier (CFPB) par rapport aux } \\
\text { ressources propres }\end{array}$ & $\begin{array}{l}\text { Un ratio faible est } \\
\text { favorable }\end{array}$ \\
\hline $\begin{array}{l}\text { L'importance des dépenses } \\
\text { incompressibles }\end{array}$ & $\begin{array}{l}\text { Dépenses de rémunération, dépenses } \\
\text { de services/charges diverses et } \\
\text { dépenses de consommation diverses } \\
\text { par rapport aux dépenses totales }\end{array}$ & $\begin{array}{l}\text { Un ratio faible est } \\
\text { favorable }\end{array}$ \\
\hline $\begin{array}{l}\text { L'importance des initiatives } \\
\text { commerciales }\end{array}$ & $\begin{array}{l}\text { Recettes de la patente par rapport au } \\
\text { produit de la population et de la } \\
\text { superficie. }\end{array}$ & $\begin{array}{l}\text { Un ratio élevé est } \\
\text { favorable }\end{array}$ \\
\hline \multicolumn{3}{|l|}{ La vulnérabilité financière } \\
\hline $\begin{array}{l}\text { La proportion des revenus } \\
\text { de taxes }\end{array}$ & $\begin{array}{l}\text { Recettes propres par rapport aux } \\
\text { recettes totales }\end{array}$ & $\begin{array}{l}\text { Un ratio faible est } \\
\text { favorable }\end{array}$ \\
\hline $\begin{array}{l}\text { La proportion de la dotation } \\
\text { du gouvernement central }\end{array}$ & $\begin{array}{l}\text { Fonds de gestion et de développement } \\
\text { des collectivités territoriales } \\
\text { (FGDCT) par rapport aux recettes } \\
\text { ordinaires }\end{array}$ & $\begin{array}{l}\text { Un ratio élevé est } \\
\text { favorable }\end{array}$ \\
\hline L'appui financier externe & $\begin{array}{l}\text { Recettes extraordinaires ajoutées du } \\
\text { FGDCT par rapport aux recettes } \\
\text { totales }\end{array}$ & $\begin{array}{l}\text { Un ratio élevé est } \\
\text { favorable }\end{array}$ \\
\hline
\end{tabular}

(b) The test on the financial situation of municipal governments

Our test is inspired by Beauregard's (2003) method, but with slight modifications to better reflect the Haitian reality. The results obtained are more relative in scope compared to the chosen comparison group and can help in understanding territorial developments, in terms of the choice of location of economic activities. They must also enable local public decision makers and taxpayers to better think about the management of their territory, within the framework of the promotion of local public goods and services. To carry out the test, five steps are necessary, as in Beauregard (2003). 
First, the group of local authorities under study was specified, justifying the validity of such a choice in relation to a group of comparison municipalities (variable standard), namely the Port-au-Prince metropolitan region.

Secondly, the ratios of the nine indicators will be calculated for all the local authorities concerned by the study.

Third, we will rank the results obtained for municipalities in order of importance with reference to the median of the study group. This median divides the group into two equally important subgroups ( $50 \%$ above and $50 \%$ below).

Fourth, the median is used to classify municipalities into three categories. The first category includes municipalities with ratios well below the median (X greater than 60\%). The second category includes municipalities with values slightly above or below the median (X between $60 \%$ and 40\%). Finally, the last category consists of municipalities with results well above the median ( $\mathrm{X}$ less than 40\%). Municipalities in the second category are identified from two boundaries around the median. Depending on the needs of the analysis, the lower and upper bounds are set at 10\% respectively around the median. They are considered to have normal values in our analysis model. As in Brown's (1993) model, we give equal weight to all ratios, the relative importance of each of them not being known. It is also assumed that the ratings from - 1 to the first category, from zero to the second and from +1 to the third are given.

Fifth, for each municipality, the sum of the scores gives the result of the test, which is an indication of its financial situation. Thus, a municipality can obtain a maximum score of 9 (which is the most favorable situation) or a minimum score of -9 (which is the most unfavorable situation). A municipality can approach the median by obtaining a score of zero (which is the normal situation) for each of its ratios.

Unlike Brown's (1993) and Beauregard's (2003) models, in our model the notions of sustainability, flexibility and vulnerability have the same weight. With three indicators each, their weight is $3 / 9$ or $1 / 3$ and therefore each of the concepts respectively represents about $33 \%$.

III- Assessment of the financial situation of the municipalities of the Western Department

From an administrative point of view, the department of West is divided into 5 districts, 20 communes and 112 communal sections. This departmental territory houses the Portau-Prince metropolitan region (the capital of the city) and the neighboring municipalities surrounding it. Since the earthquake of January 12, 2010, it has been composed of 7 municipalities (Port-au-Prince, Carrefour, Delmas, Pétion-ville, Cité Soleil, Tabarre and 
Croix-des-Bouquets). Over the years, the entire metropolitan region has become the site of a very high concentration of economic activities and socio-cultural activities and even of the population (Providence, 2018).

The first level of analysis concerns the indicators of the financial sustainability of local governments in the West Department. The three indicators are self-financing of services, self-financing of goods and capital expenditure measure their ability to mobilize own resources to ensure the provision of local services. Thus, the high values of the ratios for these indicators would reflect favorable circumstances and low values would reflect unfavorable circumstances. In other words, three cases can occur for each indicator: either favorable (ratio greater than or equal to $60 \%$, a score of +1 ), normal (ratio between $41 \%$ and $59 \%$, a score of zero), or unfavorable (at least $40 \%$, a score of -1 ). The financial viability score is calculated from the sum of the scores of the indicators and reflects the degree. In Table 2 , in addition to the ratios for each indicator, there are the scores showing the result recorded by each local government for the financial sustainability variable.

Indeed, the results show that the municipalities of the Port-au-Prince metropolitan region (Port-au-Prince, Carrefour, Delmas, Pétionville, Tabarre, Cité soleil and Croix des bouquets) experienced almost similar situations, but very different from the other municipalities in the department over the three periods. The trends in the ratios obtained show that the self-financing of services is guaranteed over the three years (favorable scores, except for the municipality of Cité Soleil for the first year with a normal score for the first indicator and the municipality of Carrefour whose score for its second indicator is normal), the self-financing of goods is also ensured (favorable scores) however, capital expenditure for these municipalities is not viable (unfavorable scores for these municipalities). Thus, the aggregate results over this three-year period suggest that the financial viability of municipalities in the Port-au-Prince metropolitan region is low, which shows a certain fragility in guaranteeing the provision of local services.

The analysis of the reality of the other municipalities in the West Department, for the financial viability variable, reveals mixed results. With scores of zero for the first two years and +2 for the last, the municipality of Gressier shows the best progress. It obtains the highest score for the 2017-2018 fiscal year, thus showing even greater financial viability, better than the municipalities in the metropolitan region. Five other municipalities are recording jagged results. These are the municipalities of Kenscoff (scores of 0.-1 and 0), Petit-Goave (for scores of -2, 2 and -1), Cabaret (as scores 1, 0 and 1) and Ganthier (for scores of $-1,-1$ and -2) respectively. These municipalities present different situations for the same dynamic of mobilizing their own resources in order to provide local services. Another trend in the results obtained refers to four other municipalities that have made some progress even when their situation remains worrying. These are the municipalities of Léogane (scores -2, -1 and 0), Grand-Goave (-3, -2 and - 
1), Anse-à-Galet (-2, -1 and -1) and Thomazeau (-3, -2 and 1). These municipalities have the worst results in the West Department and are very fragile in their situation, i.e., they are unable to mobilize sufficient revenues to ensure the sustainability of local services.

Table 2: Weight of indicators of the financial viability of the municipalities of the Department of the West

\begin{tabular}{|c|c|c|c|c|c|c|c|c|c|c|c|c|}
\hline \multirow[b]{2}{*}{ Municipalités } & \multicolumn{4}{|c|}{$2015-2016$} & \multicolumn{4}{|c|}{$2016-2017$} & \multicolumn{4}{|c|}{$2017-2018$} \\
\hline & 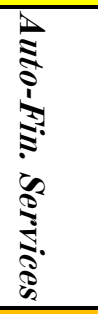 & 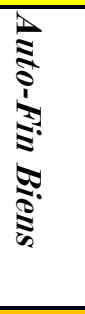 & 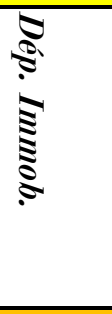 & 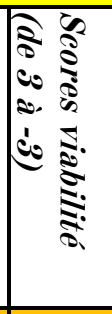 & 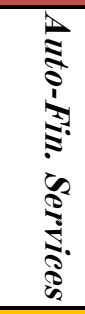 & 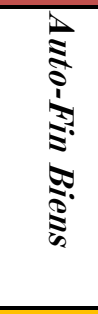 & $\begin{array}{l}8 \\
8 \\
8 \\
8 \\
8\end{array}$ & 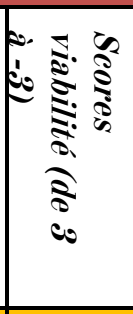 & 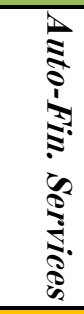 & 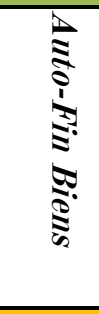 & $\stackrel{8}{8}$ & 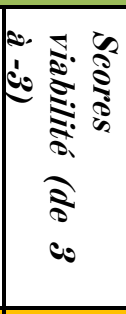 \\
\hline Port-au-Prince & 0,74 & 1,84 & 0,14 & 1 & 0,75 & 0,96 & 0,23 & 1 & 0,62 & 1,22 & 0,24 & 1 \\
\hline Carrefour & 0,87 & 1,39 & 0,29 & 1 & 0,55 & 0,74 & 0,31 & 0 & 0,74 & 0,92 & 0,36 & 1 \\
\hline Delmas & 1,39 & 1,95 & 0,31 & 1 & 1,8 & 19,4 & 0,08 & 1 & 1,26 & 2,86 & 0,22 & 1 \\
\hline Petion-Ville & 1,28 & 2,01 & 0,25 & 1 & 1,34 & 8,29 & 0 & 1 & 1,39 & 2,81 & 0,3 & 1 \\
\hline Tabarre & 1,06 & 2,5 & 0,22 & 1 & 1,21 & 3,28 & 0,18 & 1 & 1,27 & 1,69 & 0,34 & 1 \\
\hline Cité Soleil & 0,52 & 0,85 & 0,3 & 0 & 0,78 & 1,56 & 0,28 & 1 & 0,93 & 1,77 & 0,3 & 1 \\
\hline Gressier & 0,41 & 1,85 & 0,1 & 0 & 0,56 & 0,49 & 0,51 & 0 & 0,67 & 0,69 & 0,52 & 2 \\
\hline Kenscoff & 0,52 & 0,64 & 0,2 & 0 & 0,48 & 0,29 & 0,58 & -1 & 0,53 & 0,48 & 0,55 & 0 \\
\hline Leogane & 0,26 & 0,51 & 0,3 & -2 & 0,42 & 0,58 & 0,39 & -1 & 0,5 & 1,42 & 0,3 & 0 \\
\hline Grand-Goave & 0,27 & 0,41 & 0,3 & -3 & 0,4 & 0,29 & 0,53 & -2 & 0,25 & 0,72 & 0,39 & -1 \\
\hline Petit-Goave & 0,15 & 0,43 & 0,13 & -2 & 0,87 & 1,02 & 0,42 & 2 & 0,27 & 0,67 & 0,29 & -1 \\
\hline Pointe-à-Raquette & 0,06 & 0,04 & 0,63 & -1 & 0,06 & 0,03 & 0,63 & -1 & 0,29 & 1,04 & 0,36 & -1 \\
\hline Anse-à-Galet & 0,15 & 0,11 & 0,55 & -2 & 0,22 & 0,11 & 0,66 & -1 & 0,31 & 0,3 & 0,67 & -1 \\
\hline Arcahaie & 0,66 & 0,98 & 0,35 & 1 & 0,44 & 0,61 & 0,39 & 0 & 0,36 & 1,02 & 0,3 & -1 \\
\hline Cabaret & 0,94 & 1,14 & 0,28 & 1 & 0,55 & 0,47 & 0,41 & 0 & 0,74 & 0,86 & 0,33 & 1 \\
\hline Croix-Des-Bouquets & 0,85 & 2,37 & 0,23 & 1 & 0,83 & 2,74 & 0,18 & 1 & 1,22 & 2,51 & 0,3 & 1 \\
\hline Thomazeau & 0.1 & 0.28 & 0.223 & -3 & 0.2 & 0.44 & 0.29 & -2 & 0.66 & 0.27 & 0.78 & 1 \\
\hline Fonds Verrettes & 0,04 & 0,02 & 0,68 & -1 & 0,04 & 0,02 & 0,67 & -1 & 0,1 & 1,39 & 0,3 & -1 \\
\hline Ganthier & 0.54 & 0.52 & & -1 & 0.46 & 0.36 & 0.48 & -1 & 0.3 & 0.59 & 0.3 & -2 \\
\hline Cornillon/Grandbois & 0.19 & 0.1 & 0.66 & -1 & 0.2 & 0.1 & 0.62 & -1 & 0.23 & 0.51 & 0.55 & -1 \\
\hline
\end{tabular}

Table 3 introduces the second level of analysis that considers the financial flexibility variable. The latter also includes three new indicators: tax effort (based on the weight of property taxes in own revenues), incompressible expenditures (taking into account mandatory operating expenses) and the importance of business initiatives (reflecting the weight of formal entrepreneurial initiatives in each community). The first indicator 
considers that a low value of the ratio (less than or equal to $40 \%$, score +1 ) corresponds to a favorable event, i.e., that it implies a greater margin of maneuvers. The second indicator values a low ratio (less than or equal to $40 \%$, score +1 ), which makes it possible to analyze the wage bill and maintenance expenditure pea in the expenditure of these local governments. Finally, the last indicator of financial flexibility accepts as favorable a high value of the ratio (greater than or equal to $60 \%$, score +1 ) to explain the entrepreneurial dynamics in a municipal territory.

The results presented in Table 3 indicate this time a metropolitan region of Port-auPrince with four distinct financial dynamics, which is also the case for the other communes in the West Department. For the entire period (3 years), the metropolitan municipalities with the highest scores (favorable situations) for financial flexibility are Cité Soleil $(+2,+1$ and +2$)$, Tabarre $(0,+2$ and +1$)$ and Port-au-Prince $(0,+2$ and $+1)$ respectively. For the other municipalities in the department, the best performances come from the municipalities of Cabaret $(+1,+1$ and +1$)$, Cornillon $(+1,+1$ and +1$)$, Pointe-à-Raquette $(+1,+1$ and 0$)$ and Gantier $(+1,+1$ and 0$)$. The municipality of Delmas $(0,0$ and 0$)$ remains within the limits of what is acceptable, but really needs to develop a strategy to improve its financial flexibility. Thus, the results show a first category of municipalities that are sometimes in a favorable situation of financial flexibility and sometimes in an acceptable situation. This helps to understand their potential to improve their finance and thus improve their performance in the provision of local goods and services.

The second dynamic refers to municipalities whose financial flexibility has deteriorated from year to year. This is the case for the municipalities of Pétion-Ville $(0,-1$ and -1$)$, Kenscoff $(+2,-1$ and -1$)$, Arcahaie $(0,0$ and -1$)$ and Fonds Verettes $(0,1$ and -1$)$. In the case of Pétion-Ville, these results may explain a poor control of compulsory expenditure (wage bill and various consumption) and for the other municipalities in this category, the results raise questions about their tax effort and their ability to develop commercial activities. The third dynamic assumes the opposite of the second, with municipalities experiencing an improvement in their financial flexibility during this period. For the municipalities in the metropolitan region, these are Carrefour $(0,+1$ and +1$)$ and Croixdes-Bouquets $(-1,-1$ and 0$)$. For the other municipalities in the West Department, we find Gressier $(-1,-1$ and +1$)$, Anse-à-Galet $(-1,0$ and +1$)$, Tomazeau $(-1,-1$ and +1$)$ and last but not least Petit-Goave $(-3,-2$ and -2$)$. The last dynamic concerns municipalities that alternate poor results during this period. In Table 3, this category refers to the municipalities of Grand-Goave (-2, 0 and -1$)$ and Leogane (-3, -1 and -2). While municipalities in the third and fourth categories are making some efforts, their financial flexibility remains approximate and calls for a reconsideration of their governance. 
Table 3: Weight of the indicators of the financial flexibility of the municipalities of the Department of the West

\begin{tabular}{|c|c|c|c|c|c|c|c|c|c|c|c|c|}
\hline \multirow[b]{2}{*}{ Municipalité } & \multicolumn{4}{|c|}{$2015-2016$} & \multicolumn{4}{|c|}{$2016-2017$} & \multicolumn{4}{|c|}{$2017-2018$} \\
\hline & 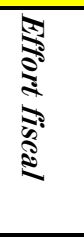 & 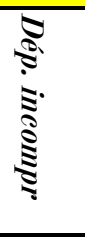 & 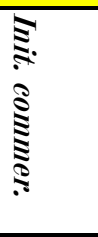 & 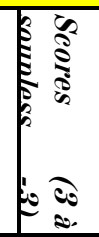 & 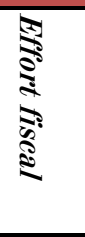 & 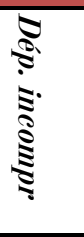 & 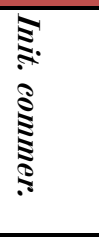 & $\begin{array}{l}c \\
0 \\
0 \\
0 \\
2\end{array}$ & 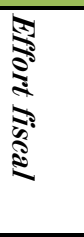 & 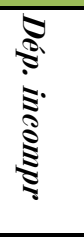 & 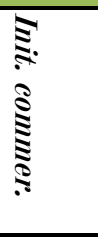 & 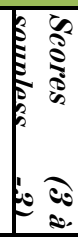 \\
\hline Port-au-Prince & 0,54 & 0,66 & 2,95 & 0 & 0,48 & 0,39 & 5,1 & 2 & 0,34 & 0,62 & 5,06 & 1 \\
\hline Carrefour & 0.74 & 0.55 & 0.36 & -1 & 0.51 & 0.49 & 0.53 & 1 & 0.44 & 0.41 & 0.64 & 1 \\
\hline Delmas & 0,65 & 0,51 & 16,26 & 0 & 0,41 & 0,92 & 24,46 & 0 & 0,41 & 0,66 & 29,82 & 0 \\
\hline Petion-Ville & 0,7 & 0,52 & 0,95 & 0 & 0,69 & 0,84 & 1,13 & -1 & 0,67 & 0,64 & 1,37 & -1 \\
\hline Tabarre & 0,46 & 0,67 & 15,67 & 0 & 0,46 & 0,7 & 19,7 & 2 & 0,42 & 0,5 & 25,91 & 1 \\
\hline Cité Soleil & 0,27 & 0,57 & 5,61 & 2 & 0,22 & 0,64 & 7,29 & 1 & 0,21 & 0,58 & 12 & 2 \\
\hline Gressier & 0,31 & 0,8 & 0,18 & -1 & 0,52 & 0,44 & 0,36 & -1 & 0,53 & 0,42 & 1,07 & 1 \\
\hline Kenscoff & 0,49 & 0,35 & 1,03 & 2 & 0,78 & 0,3 & 0,03 & -1 & 0,63 & 0,35 & 0,04 & -1 \\
\hline Leogane & 0,72 & 0,64 & 0,01 & -3 & 0,51 & 0,56 & 0,01 & -1 & 0,44 & 0,64 & 0,02 & -2 \\
\hline Grand-Goave & 0,66 & 0,53 & 0,01 & -2 & 0,55 & 0,36 & 0,02 & 0 & 0,5 & 0,51 & 0,01 & -1 \\
\hline Petit-Goave & 0,77 & 0,69 & 0,01 & -3 & 0,62 & 0,5 & 0,01 & -2 & 0,67 & 0,46 & 0,02 & -2 \\
\hline Pointe-à-Raquette & 0,15 & 0,33 & 0,01 & 1 & 0,18 & 0,31 & 0,01 & 1 & 0,03 & 0,54 & 0 & 0 \\
\hline Anse-à-Galet & 0,42 & 0,4 & 0,01 & -1 & 0,41 & 0,29 & 0,02 & 0 & 0,39 & 0,25 & 0,03 & 1 \\
\hline Arcahaie & 0,22 & 0,57 & 0,01 & 0 & 0,28 & 0,55 & 0,01 & 0 & 0,24 & 0,6 & 0,01 & -1 \\
\hline Cabaret & 0,46 & 0,4 & 0,91 & 1 & 0,61 & 0,31 & 0,65 & 1 & 0,14 & 0,35 & 2,81 & 1 \\
\hline Croix-Des-Bouquets & 0,72 & 0,73 & 0,06 & -1 & 0,69 & 0,75 & 0,04 & -1 & 0,47 & 0,63 & 0,27 & 0 \\
\hline Thomazeau & 0.16 & 0.71 & 0.01 & -1 & 0.19 & 0.68 & 0.02 & -1 & 0.04 & 0.17 & 0.03 & 1 \\
\hline Fonds Verrettes & 0,05 & 0,28 & 0 & 0 & 0,12 & 0,28 & 0 & 1 & 0,14 & 0,6 & 0 & -1 \\
\hline Ganthier & 0.01 & 0.28 & 0.01 & 1 & 0.06 & 0.35 & 0.01 & 1 & 0.08 & 0.42 & 0.03 & 0 \\
\hline Cornillon/Grandbois & 0.2 & 0.3 & 0.03 & 1 & 0.17 & 0.34 & 0.03 & 1 & 0.12 & 0.39 & 0.03 & 1 \\
\hline
\end{tabular}

The last level of analysis questions the third variable concerning the financial vulnerability of municipalities. As with the first two variables of our model, three indicators will be used to measure financial sustainability, which is seen in this paper as the degree to which municipalities are dependent on external funding. The first indicator focuses on the proportion of tax revenues, a low value of the ratio (less than or equal to $40 \%$, score +1 ) indicates a financial vulnerability of the municipality. The second indicator looks at the proportion of central government funding and the higher it is (greater than or equal to $60 \%$, score +1 ), the more financially vulnerable the municipality is. Finally, the third indicator focuses on external financial support, which indicates the municipality's financial vulnerability when the ratio is high (greater than or equal to $60 \%$, score +1 ). The more vulnerable a municipality is, the more difficult it will be to launch its own development 
process and the more its autonomy will be called into question. Table 4 presents the results (the results (the sores for each indicator) of the 20 communes in the West Department over the study period (3 years). Once again, we will be able to identify the different trends while comparing the results of the municipalities in the metropolitan region with those of the other municipalities in the West Department.

The first trend concerns municipalities with very low scores that reflect their complete financial invulnerability. Only three municipalities in the metropolitan region, which are concerned, are respectively Delmas $(-3,-3$ and -3$)$, Pétion-Ville $(-3,-3$ and -3$)$ and Tabarre $(-3,-3$ and -3$)$. The second trend indicates municipalities whose scores reveal the gradual deterioration of their situation and therefore they become vulnerable. In the metropolitan region, this is the case for the municipalities of Port-au-Prince $(-3,-3$ and $+1)$, Carrefour $(-3,-2$ and +1$)$ and Croix-des-Bouquets $(-3,-3$ and +3$)$. Two other municipalities in the West Department recorded the same results, namely Arcahaie $(-1$, +1 and +1$)$ and Kenscoff $(-1,+1$ and +1$)$. The third trend presents the case of municipalities that were vulnerable and that have gradually improved their situation. This is only the case for the municipality of Cité Soleil $(+1,-3$ and -3$)$ in the metropolitan region.

The positive trends in Table 4, in the sense of the observation of more or less pronounced financial vulnerability, present the situations of other municipalities. First, we must highlight municipalities that have remained financially vulnerable throughout the period, such as Pointe-à-Raquette $(+3,+3$ and +3$)$, Fonds Verette $(+3,+3$ and +3$)$ and Cornillon $(+3,+3$ and +3$)$ the most vulnerable. This trend is also shared by less financially vulnerable municipalities such as Gressier $(+1,+1$ and +1$)$ and Grand-Goave $(+2,+2$ and +2$)$. Then, we can notice municipalities that are still vulnerable, but that have experienced a variation over the period. These municipalities are Léogane $(+3,+1$, $+1,+1)$, Petit-Goave $(+3,-1$ and +2$)$, Anse-à-Galet $(+3,+3$ and +2$)$, Thomazeau $(+3,+1$ and +1$)$ and Ganthier $(+1,+2$ and +1$)$. These trends draw attention to the inability of these municipalities to think for themselves about the development process of these territories and to defend the principle of administrative and financial autonomy. In fact, the results (of the three variables) analyzed so far should now allow us to assess the overall financial situation of the municipalities in the Western Department, including that of the metropolitan region. 
Table 4: Weight of indicators of the financial vulnerability of the municipalities of the Department of the West

\begin{tabular}{|c|c|c|c|c|c|c|c|c|c|c|c|c|}
\hline \multirow[b]{2}{*}{ Municipalité } & \multicolumn{4}{|c|}{$2015-2016$} & \multicolumn{4}{|c|}{$2016-2017$} & \multicolumn{4}{|c|}{$2017-2018$} \\
\hline & 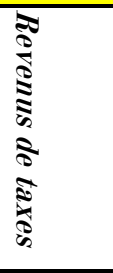 & 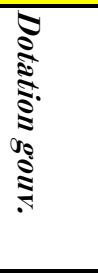 & $\begin{array}{l}3 \\
3 \\
8 \\
8 \\
8 \\
8 \\
8 \\
8 \\
8\end{array}$ & 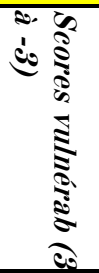 & 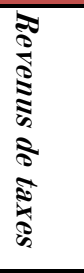 & 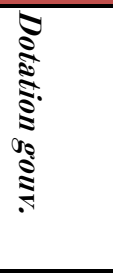 & 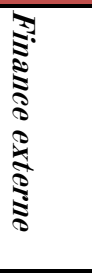 & 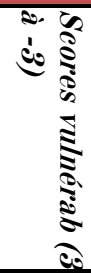 & 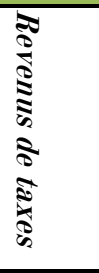 & 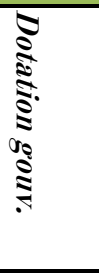 & $\begin{array}{l}\text { : } \\
8 \\
8 \\
8 \\
8 \\
8 \\
8 \\
8\end{array}$ & 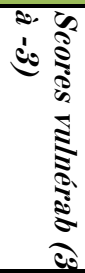 \\
\hline Port-au-Prince & 0,63 & 0 & 0,37 & -3 & 0,72 & 0,01 & 0,28 & -3 & 0,465 & 0,008 & 0,535 & -1 \\
\hline Carrefour & 0,62 & 0,13 & 0,38 & -3 & 0,45 & 0,29 & 0,37 & -2 & 0,472 & 0,129 & 0,528 & -1 \\
\hline Delmas & 0,96 & 0 & 0,04 & -3 & 0,95 & 0 & 0,05 & -3 & 0,98 & 0 & 0,02 & -3 \\
\hline Petion-Ville & 0,97 & 0,03 & 0,03 & -3 & 0,91 & 0,03 & 0,06 & -3 & 0,972 & 0,028 & 0,028 & $\overline{-3}$ \\
\hline Tabarre & 0,82 & 0 & 0,18 & -3 & 0,85 & 0 & 0,15 & -3 & 0,838 & 0 & 0,162 & -3 \\
\hline Cité Soleil & 0,36 & 0,28 & 0,64 & 1 & 0,62 & 0,1 & 0,31 & -3 & 0,655 & 0,122 & 0,345 & -3 \\
\hline Gressier & 0,37 & 0,29 & 0,63 & 1 & 0,32 & 0,2 & 0,6 & 1 & 0,324 & 0,181 & 0,676 & 1 \\
\hline Kenscoff & 0,41 & 0,2 & 0,59 & -1 & 0,23 & 0,29 & 0,67 & 1 & 0,236 & 0,242 & 0,764 & 1 \\
\hline Leogane & 0,18 & 0,67 & 0,82 & 3 & 0,29 & 0,47 & 0,45 & 1 & 0,347 & 0,327 & 0,653 & 1 \\
\hline Grand-Goave & 0,19 & 0,58 & 0,81 & 2 & 0,22 & 0,42 & 0,62 & 2 & 0,153 & 0,569 & 0,847 & 2 \\
\hline Petit Goave & 0,13 & 0,66 & 0,87 & 3 & 0,49 & 0,18 & 0,4 & -1 & 0,189 & 0,48 & 0,811 & 2 \\
\hline $\begin{array}{l}\text { Pointe-à- } \\
\text { Raquette }\end{array}$ & 0,02 & 0,92 & 0,98 & 3 & 0,02 & 0,92 & 0,71 & $\overline{3}$ & 0,182 & 0,619 & 0,818 & 3 \\
\hline Anse-à-Galet & 0,06 & 0,79 & 0,94 & 3 & 0,09 & 0,67 & 0,74 & 3 & 0,101 & 0,546 & 0,899 & 2 \\
\hline Arcahaie & 0,43 & 0,35 & 0,57 & -1 & 0,31 & 0,44 & 0,44 & 1 & 0,254 & 0,373 & 0,746 & 1 \\
\hline Cabaret & 0,68 & 0,18 & 0,32 & -3 & 0,36 & 0,34 & 0,45 & 0 & 0,497 & 0,106 & 0,503 & -1 \\
\hline $\begin{array}{l}\text { Croix-Des- } \\
\text { Bouquets } \\
\end{array}$ & 0,65 & 0,15 & 0,35 & -3 & 0,69 & 0,16 & 0,18 & -3 & 0,851 & 0,076 & 0,149 & 3 \\
\hline Thomazeau & 0.08 & 0.88 & 0.92 & 3 & 0.14 & 0.81 & 0.28 & 1 & 0.144 & 0.356 & 0.856 & 1 \\
\hline $\begin{array}{l}\text { Fonds } \\
\text { Verrettes }\end{array}$ & 0,01 & 0,95 & 0,99 & 3 & 0,01 & 0,95 & 0,71 & 3 & 0,07 & 0,875 & 0,93 & 3 \\
\hline Ganthier & 0.38 & 0.26 & 0.62 & 1 & 0.29 & 0.28 & 0.59 & 2 & 0.209 & 0.388 & 0.791 & 1 \\
\hline $\begin{array}{l}\text { Cornillon/Grd } \\
\text { Bois }\end{array}$ & 0.07 & 0.81 & 0.93 & 3 & 0.07 & 0.74 & 0.71 & 3 & 0.103 & 0.673 & 0.897 & 3 \\
\hline
\end{tabular}

Table 5 summarizes the results obtained for each municipality by aggregating the 9 indicators to determine their financial health. This table takes into account the sum of the scores to give each municipality the results for each year of our study period. To analyze the results, it is important to remember that we must compare the scores of the different municipalities, knowing that the maximum score is +9 while the minimum is -9 . In other words, the more a municipality's score tends toward +9 , the more financially healthy it is, and could plan the process of its development. On the other hand, the closer it gets to -9 as a score, the less it can cope with its public service missions and therefore local planning escapes it. The analysis of this summary table will take two forms. The first looks at the 
evolution of its financial situation for each municipality over the study period, while the second has fun comparing the scores obtained each year by our sample.

Table 5: Presentation of scores on the financial health of municipalities in the Western Department

\begin{tabular}{|l|r|r|r|}
\hline & \multicolumn{3}{|c|}{ Santé financière } \\
\hline Municipalité & 2015 - 2016 & 2016 - 2017 & 2017 -2018 \\
\hline Port-au-Prince & 4 & 6 & 3 \\
\hline Carrefour & 3 & 3 & 3 \\
\hline Delmas & 4 & 4 & 4 \\
\hline Pétion-Ville & 4 & 3 & 3 \\
\hline Tabarre & 4 & 6 & 5 \\
\hline Cité Soleil & 1 & 5 & 6 \\
\hline Gressier & -2 & -2 & 2 \\
\hline Kenscoff & 3 & -3 & -2 \\
\hline Leogane & -8 & -3 & -3 \\
\hline Grand-Goave & -7 & -4 & -4 \\
\hline Petit-Goave & -8 & 1 & -5 \\
\hline Pointe-à-Raquette & -3 & -3 & -4 \\
\hline Anse-à-Galet & -6 & -4 & -2 \\
\hline Arcahaie & 2 & -1 & -3 \\
\hline Cabaret & 5 & 1 & 3 \\
\hline Croix-Des-Bouquets & 3 & 3 & -2 \\
\hline Thomazeau & -7 & -4 & 1 \\
\hline Fonds Verrettes & -4 & -3 & -5 \\
\hline Ganthier & -1 & -2 & -3 \\
\hline Cornillon/Grand Bois & -3 & -3 & -3 \\
\hline
\end{tabular}

On the one hand, the results in Table 5 show that, overall, the municipalities in the metropolitan region obtained satisfactory scores (good financial health) over the period. The opposite is true for the other municipalities in the West Department, with the exception of Cabaret. In detail, we can note the better evolution of the financial health recorded by the municipality of Cité Soleil $(+1,+5$ and +6$)$, followed by Tabarre $(+4$, +6 and +5$)$. The municipalities of Carrefour $(+3,+3$ and +3$)$ and Delmas $(+4,+4$ and +4 ) saw a consistency in their financial health over the period. Finally, there are good students in this category from municipalities that have seen their financial health decline, such as Port-au-Prince $(+4,+6$ and +3$)$, Pétion-Ville $(+4,+3$ and +3$)$, Cabaret $(+5,+1$ and +3$)$ and Croix-des-Bouquets $(+3,+3$ and -1$)$. The results for this first category of municipalities indicate a maximum $(+6$ out of +9 possible), which indicates an acceptable, but not excellent, situation for these municipalities. 
Regarding the category of bad students, there are, first of all, municipalities whose financial health was very poor, but which has improved over the period? This is the case in the municipalities of Gressier $(-2,-2$ and +2$)$, Tomazeau $(-7,-4$ and +1$)$, Anse-àGalet (-6, -4 and -2$)$, Léogane (-8, -3 and -3$)$, Grand-Goave (-7, -4 and -4$)$ and PetitGoave $(-8,+1$ and -5$)$. Then the results reveal the cases of municipalities whose financial health was poor, but deteriorated further over time. These are the municipalities of Kenscoff ( $+3,-3$ and -2$)$, Arcahaie ( $+2,-1$ and -3$)$, Ganthier (-1, -2 and -3$)$ and Pointeà-Raquette (-3, -3 and -4$)$. The municipality of Cornillon $(-3,-3$ and -3$)$ is the only one in this category that has shown a consistent pattern of poor financial health. Thus, for this category, there is reason to be concerned about their ability not only to be autonomous, but also to think about the development process of their territory.

On the other hand, a comparative analysis of the results presented in Table 5 may reveal other elements that help to understand the situation of municipalities in the metropolitan region compared to other municipalities in the West Department. In fact, the results for the 2015-2016 fiscal year show that the municipality of Cabaret had the best financial health (score +5$)$, yet it is not part of the metropolitan region. And that the municipalities of Kenscoff $(+3)$ and Arcahaie $(+1)$ were ahead of the municipality of Cité Soleil $(+1)$. For the 2016-2017 fiscal year, the order is respected. Municipalities outside metropolitan areas with acceptable scores are: Cabaret $(+1$ only) and Petit-Goave $(+1)$. Finally, for the last year (2017-2018), the municipality of Cabaret $(+3)$ has the same financial health as Port-au-Prince $(+3)$, Carrefour $(+3)$ and Pétion-Ville $(+3)$. The municipality is significantly better ranked in relation to Croix-de-Bouquets in the metropolitan region.

\section{IV- Conclusion}

This paper seeks to fill an important gap in the literature on local public finances in Haiti by proposing an instrument to assess the financial health of the country's municipalities. It seeks to draw attention to the need to address variations in local finances in order to understand the relevance of managerial choices in the provision of local public goods and services. To this end, the main thrust of this work is to analyze the evolution of the financial health of the municipalities in the metropolitan region compared to other municipalities in the West Department. This choice is motivated by the fact that the metropolitan region receives all the attention of the central government and analysts without them really seeking to measure the impact of such a preference.

The model proposed in this paper is based on nine indicators, each of which has the same weight in the analysis. These indicators are grouped within three financial health variables to take into account the three main aspects: financial sustainability, financial flexibility and financial vulnerability. Each of the variables had a maximum score of +3 and a minimum score of -3 . When you aggregate the three variables, it gives the scores for each municipality with a maximum of +9 and a minimum of -9 . In other words, the 
municipality with the best financial health can have a score of +9 while the one with a score of -9 would have the worst financial health.

The literature review and the debates on local public finances show us two main trends. The first trend highlights that municipalities in the metropolitan region have a higher concentration rate of economic activities and population, which gives them a greater capacity to generate their own resources (self-financing). The second trend assumes that the greater the self-financing, the more autonomy is guaranteed. This leads to a better supply of local public goods and services. However, the results of our model suggest caution when analyzing the evolution of the financial health of municipalities in the metropolitan region compared to other municipalities in the Western Department.

Indeed, the fact that these trends are respected does not guarantee better results in terms of financial health. As or has been seen over the 2015-2018 period, some municipalities that are not part of the metropolitan region are in a better financial position than their competitors in this region. In addition, in all the municipalities in our study, the results are punctuated by poor performance for a score of +6 , out of a possible +9 . This suggests that the financial health of these municipalities remains fragile and that the provision of local public goods and services is not optimal. Hence the maintenance of the null hypothesis (HO) which announced that "the evolution of the financial health of municipalities does not really make it possible to distinguish those of the metropolitan region from others because of their inability to generate high self-financing."

\section{REFERENCES}

[1]. Beauregard, C. (2003). "Un instrument de mesure pour évaluer la santé financière des administrations locales." Revue de Gestion, Vol. 28, HEC Montréal, p. 66-75.

[2]. Berne, R. et Schramm, R. (1986). "The Financial Analysis of Governments ». Prentice-Hall.

[3]. Brown, K.W. (1993). "The 10-point test of financial condition: Toward an easy-to-use assessment tool for smaller cities.”Government Finance Review, December, pp. 21-26.

[4]. Clark, T.N. et Ferguson, L.C. (1998). L'argent des villes. Economica, France.

[5]. Dorner, V. (2006). La Décentralisation en Haïti. Bulletin de l'APAD, n ${ }^{\circ}$ 15, Port-au-Prince.

[6]. Guillaume O. et Providence C. (2019). Entrepreneuriat. Un levier pour le développement durable et la gestion territoriale en Haïti. Éditeur SHCOLEDGE, USA.

[7]. Institut Canadien des Comptables Agréés (ICCA). (1997). Indicateurs de l'état des finances des gouvernements. Rapport de recherche, Montréal.

[8]. Oriol, M., P. A. Guerrier et D. ST Lot (1994). Les collectivités territoriales entre 1991 et 1993 , L'Imprimeur II, Port-au-Prince, PIRED.

[9]. Providence, C. (2010). Coopération décentralisée et développement local en Hä̈ti: une étude de l'expérience de la région Aquitaine et la commune de Dondon. Mémoire de Master en Gouvernance locale, IFGCar/UAG, Martinique.

[10]. Providence C. (2015). Le système aide-projet mondial et la problématique du développement en Hä̈ti : quelles externalités locales? Thèse de doctorat en économie du développement, Université des Antilles.

[11]. Providence C. (2018). Disparités spatiales et financement des biens et services publics de proximité en Haïti. Le cas des budgets communaux de 2017-2018. Dans, CADET, R. L. "La mise en commun des activités de recherche en Économie, Éducation et Études urbaines de l'Université Quisquéya », préactes des sessions/Université Quisquéya/HSA.

DOI: http://dx.doi.org/10.19085/journal.sijmd060201 